Малюта К.Г., асист.

Вінницький торговельноекономічний інститут КНТЕУ,

м. Вінниця, Україна

\title{
ОСОБЛИВОСТІ ІНВЕСТУВАННЯ В ТУРИСТИЧНУ ГАЛУЗЬ
}

Інвестування сфери туризму $\epsilon$ важливою умовою розвитку туристичних ринків, розширення їх можливостей і масштабів, поліпшенні якості послуг, що надаються. Інвестиції відіграють важливу роль в управлінні розвитком туризму як у країні загалом, так і в регіонах [1, с. 32-33].

Можна виділити такі характерні риси інвестиційної діяльності в туризмі[2]:

- складність чіткого кількісного визначення можливого ефекту від покращення привабливості туристичного об'єкта після вкладення в нього інвестицій;

- наявність «мультиплікаційного ефекту» від туристичної діяльності, що передбачає збільшення сумарного ефекту від вкладення інвестицій на регіональному (державному) рівні;

- залученість різноманітних підприємств і видів діяльності у сферу туризму, що передбачає необхідність диференційованого підходу розміщення, залучення та управління інвестиційною діяльністю;

- особливості туристичних об'єктів, які полягають в тому, що в переважній більшості вони створені природою чи попередніми поколіннями і потребують бережливого ставлення.

Зважаючи на особливості туризму, варто враховувати i специфічність інвестиційної діяльності в туризмі. У сфері туризму можуть існувати форми і методи інвестування, які не піддаються приведенню до комерційних показників вигоди. Розширення меж поняття інвестування в туризмі дозволить інакше оцінювати інвестиційні можливості, робити їх більш привабливими[3].

При здійсненні інвестицій в туристичну індустрію слід звернути увагу, що туризм по суті своїй - явище сезонне. Іноді уряди країн дивляться на туризм досить оптимістично. 3'являються нові місця для відпочинку туристів, модернізуються старі, що прийшли в занепад: в них інвестуються гроші. Наприклад, Лівенворт (Вашингтон), старе містечко лісорубів і шахтарів, пережило справжнє відродження, коли трансформувалося в баварське селище і т. п. Часом інвестиції у туризм породжують ріст темпів інфляції. Туристи вкладають свої 
гроші, зароблені в іншому регіоні або країні, в економіку даного туристичного регіону. Підвищуються ціни на товари першої необхідності: продукти, одяг, житло, транспорт. Як правило, в туристичних регіонах особливо стрімко ростуть ціни на землю (наприклад, південне узбережжя Криму)[4, с. 183].

Отже, до переваг від інвестицій у туристичну індустрію для кожної країни, регіону можна віднести[5]:

- збільшення готівкового потоку в регіон, в тому числі надходження іноземної валюти;

- ріст валового національного продукту (ВНП), створення нових робочих місць;

- реформування структури відпочинку, яка може бути використана як туристами, так і місцевими жителями;

- залучення капіталу, в тому числі й іноземного, збільшення податкових надходжень приймаючого регіону.

Недоліки розвитку туризму проявляються в тому, що туризм:

- впливає на ріст цін на місцеві товари та послуги, на земельні й інші природні ресурси і нерухомість;

- сприяє відтоку грошей за кордон при туристичному імпорті;

- викликає екологічні та соціальні проблеми, може нанести збитки розвитку інших галузей і т. д.

\section{Список бібліографічних посилань}

1. Гавран В.Я. Управління інвестиційною діяльністю в рекреаційнотуристичній сфері: автореф. дис. канд. екон. наук: 08.02.03. Національний університет «Львівська політехніка». Львів, 2002. 34 с.

2. Охріменко А.Г. Фінансові аспекти функціонування туристичної галузі. Зб. наук. пр. Нац. ун-ту держ. податк. служби України. 2011. № 1. С. 394 - 403.

3. Школа I. М. Інвестиційна діяльність в туристичній індустрії [Електронний ресурс] - Режим доступу: https://buklib.net/books/ $33250 /$.

4. Перспективи розвитку туристичної індустрії в Україні: регіональні аспекти : матер. Всеукр. наук.-практ. інтерн.-конф. (24 березня 2016 року) / ред. кол. В. О. Стойка та ін. - Умань : Видавничополіграфічний центр «Візаві», 2016. 220 с.

5. Школа I. М. Типові інвестиційні проекти в туристичній індустрії [Електронний ресурс] - Режим доступу: https://buklib.net/books/ 33265 